\title{
Neuropsychological Screening on Acalypha indica Whole Plant Extract
}

\author{
N.V.L Suvarchala Reddy V*, Ganga Raju M, Sirisha S, Nikitha K \\ Department of Pharmacology, Gokaraju Rangaraju College of Pharmacy, Bachupally, Hyderabad, Telangana, INDIA.
}

\begin{abstract}
Objectives: Herbal treatment is a natural form of healing or alternative therapy to cure ailments or diseases of cognitive disorders. Methods: The methanolic whole plant extract of Acalypha indica was screened for its Antiepileptic and anxiolytic activity in rodent models. Molecular docking studies were employed to study interactions with GABA agonist's active site. Results: MEAl showed a significant reduction in various phases of convulsions at 30 and 60 minutes and afforded significant protection against MES model. In PTZ, MEAl at a dose of $200 \mathrm{mg} / \mathrm{kg}$ protected $66.66 \%$ of the animals against seizures and did not affect the latency of seizures to any significant extent at a dose of $400 \mathrm{mg} / \mathrm{kg}$ protected $33.33 \%$ of the mice against seizures and significantly $\left(^{*}=p<0.0001,{ }^{*}=p<0.002\right.$ ) increased the latency of the seizures. In INH induced convulsions MEAI at a dose of $(200-400 \mathrm{mg} / \mathrm{kg})$ significantly $\left(^{*}=p<0.0001, *^{*}=p<0.05\right)$ delayed the duration of $\mathrm{INH}$ induced convulsions from $57.8 \pm 2.67 \mathrm{~s}$ to $45.5 \pm 2.33,32.8 \pm 1.62$ respectively. In- vivo anti-anxiety activity MEAl at a dose of 200 and $400 \mathrm{mg} / \mathrm{kg}$ exhibited remarkable upsurge in time consumed as well as the number of entries into open arms of 200, and
\end{abstract}

$400 \mathrm{mg} / \mathrm{kg}$ exhibited noteworthy upsurge in time consumed as well as the number of entries into open arms and time spent in neutral zone. Molecular docking studies confirmed the GABA agonist's effects, and Glide scores order for all molecules reflected the experimental GABA agonists. Conclusion: From the exceeding consequences, it is vibrant that MEAI possesses antiepileptic and anti-anxiolytic activities.

Key words: Acalypha indica, Anti-epileptic, Anti-anxiolytic, GABA, glidescore, Docking.

Correspondence

Dr. N.V.L Suvarchala Reddy V,

Associate Professor, Department of Pharmacology, Gokaraju Rangaraju College of Pharmacy, Bachupally, Hyderabad- 500090, Telangana, INDIA.

Phone: +919000811806

Email: suvarchalakiran@gmail.com

DOI: 10.5530/jyp.2020.12s.52

\section{INTRODUCTION}

A seizure is a paroxysmal event due to abnormal, excessive, hypersynchronous discharges from an aggregate of central nervous system neurons. ${ }^{1}$ Epilepsy is more likely to occur in young children and the elderly. However, it can occur at any time., ${ }^{2,3}$ Anxiety is an apprehension or excessive fear about real or imagined circumstances. ${ }^{4}$ It is a highly prevalent psychological and physiological state characterized by psychomotor tension, sympathetic hyperactivity and apprehension and vigilance syndromes. ${ }^{5}$ Anxiety and epilepsy are biotic complaints that disturb one-eighth of the entire populace of the biosphere and majority of the patients existing in the emerging countries, ${ }^{6}$ Pharmacotherapeutic approaches for the management of these "modernization-borne diseases" include psychotropic drugs such as barbiturates, benzodiazepines, azapirones, norepinephrine and serotonin reuptake inhibitors, monoamine oxidase inhibitors and phenothiazines. Amongst these, benzodiazepines are the best suggested human-made chemical drugs for the cure of anxiety, insomnia, epilepsy and stress. Consistent usage of benzodiazepines reasons worsening of intellectual working, dependence, corporal necessity and tolerance. The standard anticonvulsant and anxiolytic drugs have a short range of doings with adverse effects that have limited their clinical usefulness and compromised patients' compliance. Thus, there is a requirement to quest for newer agents with improved clinical outlines for the release of anxiety indicators and the cure of convulsions. Thus, there is a need to search for newer agents with better clinical profiles for the relief of anxiety symptoms and treatment of convulsions. ${ }^{7,8}$ Researchers of today are exploring natural resources to discover safer and cost-effective drugs. Investigating plants, based on their use in traditional systems of medicine, is a sound, viable and cost-effective strategy to develop new drugs.
Acalypha indica Linn. (Family; Euphorbiaceae), commonly known as Indian copper leaf in English and other vernacular names includes, Kuppameni, Kuppi and Harittamanjari. The whole plant of A. indica is used in the traditional medicinal system to treat various diseases. In Ayurveda, A. indica used as a laxative, anthelmintic, emetic, expectorant and also used to treat scabies, earache, syphilitic ulcers and snake bites. In Siddha medicine, $A$. indica is used to treat diseases associated with teeth and gums, stomach aches, irritations, burns, wheezing and respiratory diseases. This plant has been studied for antidiabetic, wound healing, postcoital infertility, antivenom, antiulcer, antimalarial, antiinflammatory, antimicrobial, alpha-amylase inhibitor, neuroprotective and antioxidant activities. Hence the current study has been assumed to explicate the anxiolytic and anticonvulsant effect of methanolic extract of Acalypha indica Linn.

\section{MATERIALS AND METHODS}

\section{Plant material}

The whole plant of Acalypha indica was collected from Hyderabad, Telangana in November and was identified taxonomically and authenticated by P. Suresh Babu, Head Department of Botany, New Government Degree College, Kukatpally.

\section{Preparation of methanolic extract}

The whole plant of Acalypha indica was collected, cleaned, dried under shade for about six days and coarsely powdered in a mixer grinder. The powdered material was stored and taken up for the Soxhlet extraction process. The $300 \mathrm{~g}$ of the powdered plant is packed in the Soxhlet 
apparatus directly or in a thimble of a filter paper. Later the methanolic solvent is allowed to pass through a siphon tube once before heating. The organic extracts obtained were evaporated to dryness by keeping at room temperature. ${ }^{9}$

\section{Preliminary phytochemical analysis}

The Methanolic extract of Acalypha indica (MEAI) was subjected to preliminary phytochemical investigation. ${ }^{10}$

\section{Animals}

Adult Wistar albino rats (180 -200 g) and Swiss albino mice (20 -25 g) were used for the pharmacological activities. They remained in polypropylene cages at $25 \pm 2^{\circ} \mathrm{C}$ with relative humidity $45-55 \%$ under $12 \mathrm{hr}$ light and dark cycles. All the animals were adjusted to the laboratory surroundings for a week earlier use. They were nourished with standard animal feed and water ad libitum. All the experimental protocols were approved by the Institutional animal ethics committee (IAEC).

\section{Acute oral toxicity}

Acute toxicity studies for Methanolic extract of Acalypha indica Linn was conducted as per OECD guidelines No.425 using Swiss albino mice. The animals were administered with a single dose of $(2000 \mathrm{mg} / \mathrm{kg})$ of extract and perceived for any alterations unceasingly for the first $2 \mathrm{~h}$ then for $24 \mathrm{~h}$ and $72 \mathrm{~h}$ for any lethality. And up to 14 days for any toxic symptoms. ${ }^{11}$

\section{Assessment of antiepileptic activity Maximum electroshock convulsions test (MES)}

The study is carried out for 5 days by taking 24 healthy Wistar albino rats of either Sex, weighing 180-220 gm. Then the animals were treated with distilled water, test drugs and the standard drug Phenytoin $(90 \mathrm{mg} / \mathrm{kg}$, bd.wt. i.p) before the application of electric shock to the animals. After 30 and $60 \mathrm{~min}$, convulsions were produced in rats by using electroconvulsive meter by delivering a current of $150 \mathrm{~mA}$ through corneal electrodes for $0.2 \mathrm{sec}$. The duration of Flexion, extension assessed the severity of convulsions and jerky movements are determined. ${ }^{12}$

\section{Pentylenetetrazole (Metrazol) Induced convulsions (PTZ)}

The method was performed for the anti-convulsant property of drugs by taking 24 healthy Swiss albino mice of either sex, weighing 20-25 gm. The test drugs are administered orally with the standard drug diazepam ( $2 \mathrm{mg} / \mathrm{kg}$, bd. wt. i.p) $30 \mathrm{~min}$ later convulsions were induced by the intraperitoneal administration of ( $90 \mathrm{mg} / \mathrm{kg}$, bd. wt.) of PTZ. Following the administration of PTZ, mice were placed in separate cages and observed for the occurrence of seizures over $30 \mathrm{~min}$ of the period. Later the latency of convulsions (the time before the onset of tonic convulsions), duration of tonic convulsions and mortality protection (percentage of deaths in $24 \mathrm{~h}$ ) is recorded. ${ }^{13}$

\section{Isoniazid induced convulsions (INH)}

24 healthy Swiss albino mice of either sex, weighing 20-25 gm, were taken. The test drugs are administered orally with the standard drug diazepam (4mg/kg, bd .wt. p.o). 30 min later convulsions were induced by the subcutaneous administration of $(75 \mathrm{mg} / \mathrm{kg}$, bd.wt.) of INH. During the next 120 min time, the latency of the first clonic convulsions, duration and mortality protection (percentage of deaths in $24 \mathrm{~h}$ ) were recorded. ${ }^{14}$

\section{Anxiolytic activity \\ Elevated plus-maze model (EPM)}

The Elevated plus maze (EPM) test is used to study the spontaneous behavior of animals. It consisted of two open arms $(30 \times 5 \mathrm{~cm})$ and two closed arms $(30 \mathrm{~cm} \times 5 \mathrm{~cm} \times 15 \mathrm{~cm})$ extending from a central platform and was elevated to a height of $50 \mathrm{~cm}$ above the floor. Albino mice weighing 20-25 gm were taken. The test drugs are administered orally with the standard drug diazepam ( $3 \mathrm{mg} / \mathrm{kg}$, bd. wt. i.p) one hour after the treatment each mouse were individually placed at the centre of the maze, their heads facing an open arm and allowed to explore the maze for $5 \mathrm{~min}$. During the period, the behaviours of the mice are recorded; Number of entries into the open and closed arm, time spent in open and closed arms and time spent in neutral zone. ${ }^{15}$

\section{Docking studies}

Molecular docking is a kind of bioinformatics modelling which involves the interaction of two or more molecules to give the stable adduct. Depending upon binding properties of legend and target, it predicts the three-dimensional structure of any complexity. The practical application of molecular docking requires data bank for the search of the target with proper PDB format and a methodology to prepare legend as a PDB file. Glide 5.6 (Schrodinger Inc) was used for generating docking simulation studies. Docking simulation was performed in Dell precession T-1500 workstation Intel (R) Core (TM)

i7 CPU 860@GHz; 12.0 GB Ram, 1 TB Hard disk protein-ligand interactions were visualized using Maestro 9.1. GABA agonists suppress seizures and GABA antagonists produce seizures. GABA seems to show a significant role in the pathogenesis of numerous neuropsychiatric ailments. The agents which upsurge the brain GABA content and administration of centrally active GABA mimetic agents have been used as an effective therapeutic approach for the treatment of anxiety and epilepsy. The 2D legends (* mol) sketched in chem. draw 8.0 were imported into Maestro 9.1 workspace and were exported as ${ }^{\star}$ Mae files. The energy of the legends was optimized and saved as sdf file. The structure of GABA agonist (PDB ID: 4MS4) was retrieved from the RCSB protein bank. Receptor grid was generated on the centred legend with scaling factor 1. Protein-legend interactions were stimulated though flexible glide- legend docking with XP extra precision mode. The resulting docking posses were visualized through the maestro 9.1 workspaces. The hydrogen bonding and hydrophobic interactions were visualized to know the binding interactions between ligands and protein. The bestdocked structures were chosen using the glide score function. The more negative the glide scores, the more favourable the binding. ${ }^{16}$

\section{RESULTS}

\section{Preliminary photochemical analysis}

Preliminary photochemical analysis of a methanolic extract of Acalypha indica showed the presence of Tannins, Saponins, Steroids, Alkaloids, Carbohydrates and Flavonoids.

\section{Acute toxicity studies}

There was no mortality and noticeable behavioural changes in all the groups tested. The extract was found to be safe up to a dose level of $2000 \mathrm{mg} / \mathrm{kg}$ body weight.

\section{Antiepileptic activity}

Methanolic extract of Acalypha indica whole plant was explored for its antiepileptic activity by Maximal electro shock-induced convulsions in rat models. All the results obtained in this study were included below.

\section{Maximal electro shock-induced convulsions}

In maximal electro shock-induced convulsion, there were various phases of convulsions when compared with the control group; there were significantly decreased in the MEAI extract at a dose of $200 \mathrm{mg} / \mathrm{kg}$. At $30 \mathrm{~min}$ and $60 \mathrm{~min}$, whereas when compared with the control group 
Table 1: Effect of MEAl on Maximal electro shock induced convulsions (MES).

\begin{tabular}{|c|c|c|c|c|c|c|}
\hline \multirow{2}{*}{ Groups } & \multicolumn{3}{|c|}{$30 \mathrm{~min}$} & \multicolumn{3}{|c|}{$60 \mathrm{~min}$} \\
\hline & Flexion & Extension & Jerky movements & Flexion & Extension & Jerky movements \\
\hline Control & $22.2 \pm 1.4$ & $13.5 \pm 0.67$ & $21.3 \pm 1.52$ & $23.2 \pm 0.74$ & $15.8 \pm 1.13$ & $19.3 \pm 1.855$ \\
\hline MEAI200 mg/kg & $13.5 \pm 1.05^{* * a}$ & $11.6 \pm 0.84^{\mathrm{a}}$ & $14.6 \pm 1.30^{* \star b}$ & $7 \pm 0.36^{* * a}$ & $3.5 \pm 0.223^{* \mathrm{~ns}}$ & $7.3 \pm 0.333^{* \mathrm{~ns}}$ \\
\hline MEAI400 mg $/ \mathrm{kg}$ & $11.3 \pm 0.33^{* \times b}$ & $6.7 \pm 0.66^{* \mathrm{~b}}$ & $12.6 \pm 0.42^{* \mathrm{~ns}}$ & $4.5 \pm 0.34^{* * \mathrm{~b}}$ & $2.8 \pm 0.401^{* \mathrm{~ns}}$ & $4.7 \pm 0.210^{-* \mathrm{~ns}}$ \\
\hline Phenytoin (90 mg/kg) & $7.6 \pm 0.42^{* *}$ & $2.7 \pm 0.42^{* *}$ & $9.2 \pm 0.79^{* *}$ & $2.2 \pm 0.30^{* *}$ & $1.5 \pm 0.223^{* *}$ & $4 \pm 0.2581^{* *}$ \\
\hline
\end{tabular}

Values are expressed as Mean $\pm \operatorname{SEM}(n=6)$. Statistical analysis was performed by using ANOVA followed by

Dunnet's test. Significant values were expressed as $\left({ }^{* *}=p<0.01\right)$ when compared to control group and standard $\left({ }^{\mathrm{a}}=p<0.01,{ }^{\mathrm{b}}=p<0.05\right)$, ${ }^{\mathrm{ns}}=$ non significant.

Table 2: Effect of MEAI on Pentylenetetrazole induced convulsions (PTZ).

\begin{tabular}{ccccc}
\hline Groups & $\begin{array}{c}\text { Latency of } \\
\text { convulsions }\end{array}$ & $\begin{array}{c}\text { Duration of } \\
\text { convulsions }\end{array}$ & Mortality & $\begin{array}{c}\% \\
\text { protection }\end{array}$ \\
\hline Disease control & $91.83 \pm 3.32$ & $168.16 \pm 2.6760$ & $5 / 6$ & 16.66 \\
MEAI $200 \mathrm{mg} / \mathrm{kg}$ & $134.83 \pm 3.77^{* * a}$ & $154.833 \pm 1.77^{* a}$ & $2 / 6$ & 33.33 \\
MEAI $400 \mathrm{mg} / \mathrm{kg}$ & $223.66 \pm 4.50^{* * a}$ & $142.33 \pm 2.23^{* * a}$ & $4 / 6$ & 66.66 \\
Diazepam $(2 \mathrm{mg} / \mathrm{kg})$ & $407.33 \pm 6.82^{* *}$ & $118.33 \pm 2.66^{* *}$ & $1 / 6$ & 83.34 \\
\hline
\end{tabular}

Values are expressed as Mean $\pm \operatorname{SEM}(n=6)$. Statistical analysis was performed by using ANOVA followed by Dunnett's test. Significant values were expressed as $\left(^{* *}=p<0.01\right)$ when compared to disease control and $\left({ }^{a}=p<0.01\right)$ when compared to standard group.
Table 3: Effect of MEAI on Isoniazid induced convulsions.

\begin{tabular}{ccccc}
\hline Groups & $\begin{array}{c}\text { latency } \\
\text { of tonic } \\
\text { convulsions }\end{array}$ & $\begin{array}{c}\text { Duration } \\
\text { of tonic } \\
\text { convulsions }\end{array}$ & Mortality & $\begin{array}{c}\% \\
\text { protection }\end{array}$ \\
\hline Disease control & $81.1 \pm 5.03$ & $57.8 \pm 2.67$ & 616 & 0.0000 \\
MEAI $200 \mathrm{mg} / \mathrm{kg}$ & $267.3 \pm 11.2^{* * a}$ & $45.5 \pm 2.33^{* a}$ & 416 & 33.33 \\
MEAI $400 \mathrm{mg} / \mathrm{kg}$ & $341.3 \pm 15.1^{* * a}$ & $32.8 \pm 1.62^{* * \mathrm{~b}}$ & 216 & 66.66 \\
diazepam $(4 \mathrm{mg} / \mathrm{kg})$ & $505 \pm 8.83^{* *}$ & $24.8 \pm 1.72^{* *}$ & 116 & 83.33 \\
\hline
\end{tabular}

Values are expressed as Mean $\pm \operatorname{SEM}(n=6)$. Statistical analysis was performed by using ANOVA

Followed by Dunnett's test. Significant values were expressed as $\left({ }^{* *}=p<0.01\right.$, * $=p<0.05)$ when

Compared to disease control and $\left({ }^{\mathrm{a}}=p<0.01,{ }^{\mathrm{b}}=p<0.05\right)$ when compared to standard.

Table 4: Effect of MEAI on Anti- anxiety Parameter by Elevated plus maze model.

\begin{tabular}{|c|c|c|c|c|c|}
\hline \multirow{2}{*}{ Groups } & \multicolumn{2}{|c|}{ Time spent in arms } & \multicolumn{2}{|c|}{ Num of entries } & \multirow{2}{*}{$\begin{array}{l}\text { Time spent in neutral } \\
\text { zone }\end{array}$} \\
\hline & Open & Closed & Open & closed & \\
\hline Control & $17.5 \pm 2.76$ & $269 \pm 4.14$ & $3.16 \pm 0.31$ & $7.83 \pm 0.47$ & $12.6 \pm 2.70$ \\
\hline MEAI $200 \mathrm{mg} / \mathrm{kg}$ & $149 \pm 13.89^{* * a}$ & $121 \pm 15.25^{* * a}$ & $7 \pm 0.5163^{* * a}$ & $5.83 \pm 0.40^{* a}$ & $28.8 \pm 2.32^{* * a}$ \\
\hline MEAI $400 \mathrm{mg} / \mathrm{kg}$ & $206 \pm 4.93^{* * a}$ & $71.6 \pm 5.401^{* \times b}$ & $9.66 \pm 0.49^{* * b}$ & $5 \pm 0.36^{* \star b}$ & $21.8 \pm 2.48^{* b}$ \\
\hline Diazepam (3 mg/kg) & $258 \pm 6.26^{* *}$ & $29.6 \pm 4.75^{* *}$ & $12.5 \pm 0.99^{* *}$ & $3.5 \pm 0.22^{* *}$ & $12.6 \pm 1.64^{\mathrm{ns}}$ \\
\hline
\end{tabular}

Values are expressed as Mean \pm SEM $(n=6)$. Statistical analysis was performed by using ANOVA followed by Dunnett's test. Significant values were expressed as $\left({ }^{* *}=p<0.01,{ }^{*}=p<0.05\right)$ when compared to control group and $\left({ }^{\mathrm{a}}=p<0.01,{ }^{\mathrm{b}}=p<0.05\right)$ when compared to standard group.

test extract at a dose of $400 \mathrm{mg} / \mathrm{kg}$ were significantly decreased when compared to the control group depicted in Table 1.

\section{Pentylenetetrazole induced convulsions}

Pentylenetetrazole produced seizures in the entire animals. MEAI, at a dose of $200 \mathrm{mg} / \mathrm{kg}$, protected the animals with 33.33\% against seizures and showed the onset (latency) of seizures significantly. MEAI at a dose of $400 \mathrm{mg} / \mathrm{kg}$ and standard (diazepam $2 \mathrm{mg} / \mathrm{kg}$ ) protected $66.66 \%$ and $83.34 \%$ of the mice against seizures significantly increased the latency of seizures shown in Table 2.

\section{Isoniazid induced convulsions}

Isoniazid elicited convulsions in all the animals used. The disease control group produced convulsions and showed a latency of $81.1 \pm 5.03$. The methanolic extract of Acalypha indica at a dose of 200 and $400 \mathrm{mg} / \mathrm{kg}$ significantly delayed the duration of convulsions from $81.1 \pm 5.03$ to $267.3 \pm 11.2,341.3 \pm 15.1$. Diazepam at a dose of $4 \mathrm{mg} / \mathrm{kg}$ significantly increased the latency of Isoniazid seizures and reduced the duration from $57.8 \pm 2.67$ to $24.8 \pm 1.72$ with $83.33 \%$ protection in Table 3 .

\section{Elevated plus maze test}

The elevated plus-maze test is used to study the spontaneous behaviour of animals. MEAI at a dose of 2400 and $400 \mathrm{mg} / \mathrm{kg}$ showed a significant increase in time spent as well as several entries into open arms and as well as an increase in time spent in the neutral zone when compared to the control group given in Table 4 .

\section{Molecular docking studies}

Docking studies are done for the compounds which have good binding ability with GABA protein (PDB ID: 4MS4)

\section{DISCUSSION}

In the present study, the Antiepileptic activity of Acalypha indica was evaluated by three different screening models. MES, PTZ and INH induced convulsions. MES is a standard procedure that evaluates the testing materials> ability to protect against Hind limb extension in MES. It is a suitable model for grand mal epilepsy. The electroshock delivered in MES model is known to potentiate the sodium influx through the 


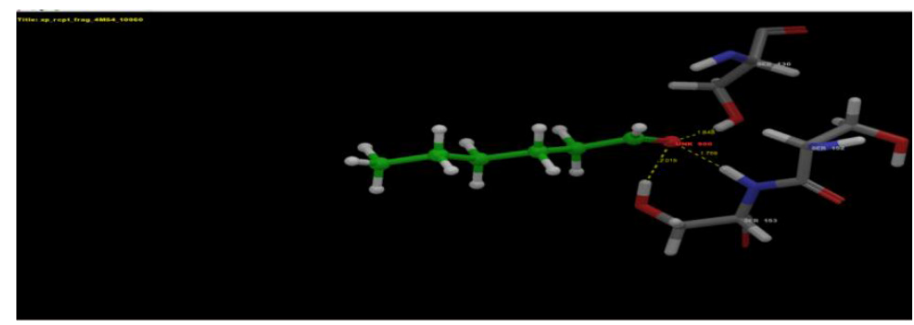

Figure 1: Hydrogen bonding interactions of hex anal with PDB ID: 4MS4 Hex anal (total score -7.70) by hydrophobic interactions with Ser 130, Ser 152 and Ser 153 .

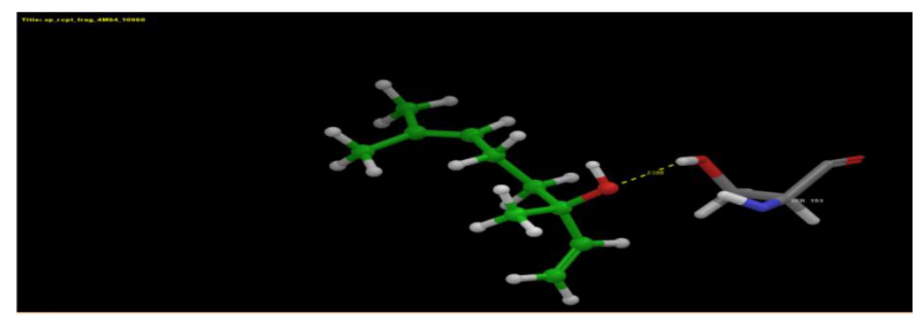

Figure 2: Hydrogen bonding interactions of linalool with PDB ID: 4MS4 Linalool (total score -5.82) by hydrophobic interactions with Ser 153.

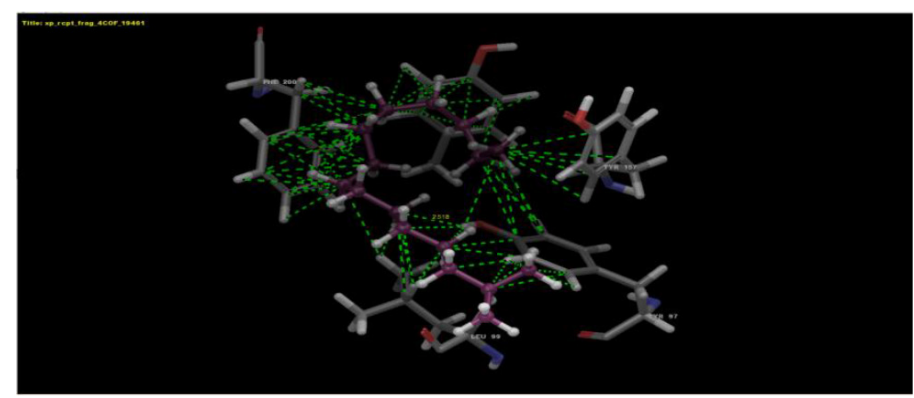

Figure 3: Hydrogen bonding interactions of 2- methyl pentade cane with PDB ID: 4MS4, 2- Methyl pentade cane (total score -1.41) by hydrophobic interactions withPhe 200, Tyr 157, Leu 99 and Tyr 97.

opening of sodium channels and also increase glutamate levels, which binds with NMDA receptors ${ }^{17}$ MEAI at a dose of 200 and $400 \mathrm{mg} / \mathrm{kg}$ showed a significant reduction in various phases of convulsions at 30 and 60 minutes time intervals when compared with the control group and showed significant protection against MES model. It is understood that the agents which could block the voltage-dependent sodium channels (Phenytoin, sodium valproate) and the agents that decrease the levels of excitatory amino acids or antagonize their actions to be effective in MES-induced epilepsy model. ${ }^{18}$ In PTZ, convulsions are produced due to alterations of GABA levels in the brain. It is a suitable model for petit mal epilepsy. The basic mechanism of PTZ is that it induces seizures by antagonizing the inhibitory GAB Aergic neurotransmission and calcium channel blockade and also increasing the level of the excitatory neurotransmitter, causing neuronal excite toxicity leads to seizure development. ${ }^{19,20}$ In the present study MEAI at a dose of $200 \mathrm{mg} / \mathrm{kg}$ protected $33.33 \%$ of the mice against seizures and did not affect the latency of seizures to any significant extent and at a dose of $400 \mathrm{mg} /$ $\mathrm{kg}$ protected $66.66 \%$ of the mice against seizures and significantly $\left({ }^{*}=\mathrm{p}\right.$ $\left.<0.0001,{ }^{* *}=p=0.002\right)$ increased the latency of the seizures. Furthermore, PTZ-induced seizures can be prevented by drugs that reduce T-type
$\mathrm{Ca}^{2+}$ currents. INH is regarded as a GABA synthesis inhibitor. In INH induced convulsions, they are some proposed mechanisms; one of these is pyridoxine deficiency (vita B6) caused by Isoniazid therapy that leads to a decrease in GABA, resulting in the reduced threshold for convulsions. Pyridoxal 5 phosphate is an active form of pyridoxine, and it is a co-factor for glutamic acid decarboxylase, which is required for GABA synthesis. Isoniazid inhibits GAD by binding to Pyridoxal 5phosphate and reduces the synthesis of GABA. ${ }^{21,22}$ In the present study, INH in disease control group convulsions were produced and showed the latency of $81.1 \pm 5.03 \mathrm{~s}$. In MEAI at a dose of $(200-400 \mathrm{mg} / \mathrm{kg})$ significantly $\left({ }^{*}=p<0.0001,{ }^{* *}=p<0.05\right)$ delayed the duration of tonic convulsions from $57.8 \pm 2.67 \mathrm{~s}$ to $45.5 \pm 2.33$, and $32.8 \pm 1.62$ respectively. In the present study, the anxiolytic activity of Acalypha indica was evaluated by one screening model, i.e., Elevated plus maze test to evaluate psychomotor performance and emotional aspects of rodents. The exact mechanism is not known, but it may be due to the involvement of GABAergic, serotonergic involvement. ${ }^{23}$ MEAI at a dose of 200 and $400 \mathrm{mg} / \mathrm{kg}$ showed a significant increase in time spent as well as several entries into open arms and time spent in the neutral zone when compared to control.

\section{Docking studies}

In silico molecular docking is a method with predicts the preferred orientation of a molecule. In the present study, four compounds have been docked, i.e., Terpenoids (linalool, 2-methylpentadecane, hexanal, hexenol). The observed glide scores are linalool (-5.82) Hexenol (-7.64) Hexanal (-7.70) 2-methylpentadecane (-1.41) among this linalool, hexenol, and hexanal were found to be ideal and depicted in the Figure $1-3 .^{24}$

\section{CONCLUSION}

Preliminary phytochemical investigation of methanolic extract of Acalypha indica showed the presence of Tannins, Saponins, steroids, Alkaloids, carbohydrates, terpenoids and flavonoids. The extract was screened for MES induced, PTZ induced and INH induced convulsions and was found to possess significant anticonvulsant property by the possible mechanisms of MEAI may be due to enhanced GABA levels in the brain. The extract significantly increased the time spent as well as number of entries into the open arms and time spent in neutral zone when compared to control group and was found to possess anxiolytic activity. The present study revealed that methanolic extract of Acalypha indica possess significant anti-convulsant and anxiolytic effects and these findings collaborate with the ethno medicinal uses of this plant. Further isolation of active chemicals from this plant might serve as lead compounds for the synthesis of drugs which could be used in the management of these nervous disorders.

\section{ACKNOWLEDGEMENT}

The authors are grateful to the principal and management of the Gokaraju Rangaraju College of pharmacy, for the constant support and encouragement during the course of the work.

\section{CONFLICT OF INTEREST}

All authors have no conflicts of interest to declare

\section{ABBREVIATIONS}

MEAI: Methanolic extract of Acalypha indica; PTZ: pentylenetetrazol; GABA: Gamma Amino Butyric Acid; MES: Maximum electroshock; INH: Isonicotininc acid Hydrazide; IAEC: Institutional animal ethics committee; OECD: The Organisation for Economic Co-operation and 
Development; EPM: Elevated plus-maze model; NMDA: N-methyl-Daspartate.

\section{REFERENCES}

1. Daniel H. Lowenstein; Seizures and epilepsy, Harrisons Principles of Internal Medicine, Mc Graw Hill, 17th edition. 2020;2498.

2. Ganga Raju M, Fernandes J, Vijayanarayana K. Evaluation of antiepileptic activity of the alcoholic extract of Adhatoda vasica leaves in rats. Res J Pharm Biol Chem Sci, 2011;2(3):5-10.

3. Pradeep K, Ishpinder S, Nanjaian M, Gagandeep C. Anticonvulsants From Nature. Phcog Rev. 2009;3(5):108-17.

4. Shalini S, Swathi K, Mohan P, Swapna K, Ramesh BP, Chandrika S. Anti Epileptic Activity of Enicostema Axillare against MES and PTZ Induced Seizures in Rats. International Journal of Innovative Pharmaceutical Research. 2011;2(1):94-7.

5. Huerta-Reyes M, Herrera-Ruiz M, Gonzalez-Cortazar M, Zamilpa A, Leon E, Reyes-Chilpa $R$, et al. Neuropharmacological in vivo effects and phytochemical profile of the extract from the aerial parts Heteropterys brachiata (L.) DC (Malpighiaceae). Journal of Ethnopharmacology. 2013;146(1):311-7.

6. Mansouri MT, Soltani M, Naghizadeh M, Farbood Y, Mashak A, Sarkaki A. A possible mechanism for anxiolyticlike effect of gallic acid in the rat elevated plus maze. Pharmacology Biochemistry and Behavior. 2014;117:40-6.

7. Mahendran G, Thamotharan G, Sengottuvelu S, Narmatha BV. Evaluation of Anticonvulsant, Sedative, Anxiolytic and Phytochemical Profile of the Methanol Extract from the Aerial Parts of Swertia corymbosa (Griseb.) Wight ex C.B. Clarke. Bio Med Research International. 2014

8. Gayoso LC, Moreno AI, Oliveira GZDS. Development and evaluation of liposoma formulation containing nimodipine on anxiolytic activity in mice. Pharmacology, Biochemistry and Behavior. 2014;116:64-8.

9. Walf F. A review and update of mechanisms of estrogen in the hippocampus and amygdala for anxiety and depression behavior. Neuropsycho Pharmacology. 2006;31(6):1097-111.

10. Syahiran N, Syafiqah S, Razauden Z, Idayu M, Harisun Y, Hadi N. A review of Acalypha indica L. (Euphorbiaceae) as traditional medicinal plant and its therapeutic potential. Journal of Ethnopharmacology: Elsevier. 2017;207:146-73.

11. Rangari V. Pharmacognosy and phytochemistry. $1^{\text {st }}$ ed. Nashik, Maharashtra; Career Publications. 2009

12. Kandelwal KR. Practical Pharmacognosy Techniques and Experiments. $1^{\text {st }}$ ed.
Pune: Nirali Prakashan. 2005;30-149.

13. Bruce RD. An up-and-down Procedure for Acute Toxicity Testing. Fundamentals of Applications Toxicology. 1985;5(1):151-7.

14. Suri R, Abu H, Noor A, Rosnah O, Normah A. Preliminary studies on the analysis of fatty acids, essential oils and flavonoids in Acalypha indica L. Journal of Tropical Agriculture and Food Science. 2004;32(2):163-9.

15. Madhu A, Keerthi PHV Jaideep S, Shivalinge GKP. To evaluate the antiepileptic activity of aqueous root extract of Hemidesmus indicus in rats. Arch Pharm Sci and Res 2009;1(1):43-7.

16. Thirupathy K, Saravanan A. Anticonvulsant activity of Morinda tinctoria-Roxb. Afri J Pharm and Pharmacol. 2009;3(2):63-5.

17. Mahendran G, Thamotharan G, Sengottuvelu S, Narmatha BV. Evaluation of Anticonvulsant, Sedative, Anxiolytic and Phytochemical Profile of the Methanol Extract from the Aerial Parts of Swertia corymbosa (Griseb.) Wight ex C.B. Clarke. Biomed Research International. 2014;1-9.

18. Pitchaiah G, Anusha VL, Hemalatha CH, Anil KY, Sravani K. Anxiolytic and Anticonvulsant activity of methanolic extract of Allium cepa Linn (Onion) bulbs in Swiss albino mice. Journal of Pharmacognosy and Phytochemistry. 2015;4(2):131-5

19. Karim N, Khan I, Abdelhalim A, Abdel-Halim H, Hanrahan J. Molecular docking and antiamnesic effects of nepitrin isolated from Rosmarinus officinalis on Scopolamine-induced memory impairement in mice. Biomedical and Pharmacotherapy. 2017:96:700-9.

20. Shweta M, Dahima R. In-vitro ADME studies of TUG-891, a GPR-120 inhibito using Swiss ADME predictor. Journal of Drug Delivery and Therapeutics. 2019;9(2-s):366-9. ISSN: 2250-1177.

21. Gollapalle LV, Marikunte VV, Bheema LP, Godavarthi A. Evaluation of antiepileptic activity of leaf extracts of Punica granatum on experimental models of epilepsy in mice. Journal of Intercultural Ethnopharmacology. 2016;5(4):415-21.

22. Eerike M, Venu GR, Ruckmani A, Umar D. Evaluation of antiepileptic activity of ethanolic extract of Azima Tetracantha Root in mice. International Journal of Current Pharmaceutical Research. 2016;8(4):76-9. ISSN: 0975-7066,

23. Amol S, Aiwale A, Patel MJ, Pramod JHAR, Chandrabhanu T. Isoniazid induced convulsions at Therapeutic dose in an alcoholic and smoker patients. Current Drug Safety. 2015;10(1):94-5.

24. Geethu K, Vishnupriya K, Thamodaran G, Suresh V, Senthil K. Evaluation of anticonvulsant and anxiolytic activity of methanolic extracts of leaves of Syzygium aqueum (Brum.f). European Journal of Pharmaceutical and Medical Research. 2017:4(12):224-30.

Article History: Submission Date : 18-03-2020; Revised Date : 03-05-2020; Acceptance Date : 23-05-2020x.

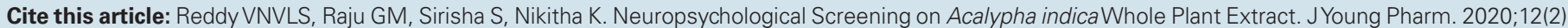
Suppl:s82-s6. 